\title{
Giant cell vasculitis and microscopic (collagenous-lymphocytic) colitis
}

\author{
HUGH JAMES FREEMAN, MD
}

HJ FrEEMAN. Giant cell vasculitis and microscopic (collagenous-lymphocytic) colitis. Can J Gastroenterol 1993;7(8):616-620. A 55-year-old female with watery diarrhea for over 20 years was found to have microscopic (collagenous) colitis in 1986. During her subsequent clinical course, colonic biopsies revealed typical pathological features of both lymphocytic and collagenous colitis. The patient developed fever, malaise, headache, multiple vascular bruits and an elevated sedimentation rate. Although a large vessel vasculitis was suspected, biopsy of the temporal artery was normal. Subsequent arch aortography and selective arterial catheterization studies revealed multiple vascular stenoses and occlusions; despite its very atypical clinical presentation, a biopsy of an occluded brachial artery revealed characteristic features of giant cell arteritis. Steroid therapy resulted in prompt clinical remission. The clinical spectrum of findings in this patient further supports the concept that collagenous colitis and, possibly, other histologically related forms of microscopic colitis, such as lymphocytic colitis, may be pathological markers of a more generalized immunological disorder.

Key Words: Collagenous colitis, Giant cell vasculitis, Granulomatous, Inflammatory bowel disease, Lymphocytic colitis, Microscopic colitis, Temporal arteritis

\section{Vasculite à cellules géantes et colite microscopique (collagénique-lymphocytaire)}

RÉSUMÉ : Une femme de 55 ans présentant une diarrhée aqueuse depuis plus de 20 ans s'est révélée avoir une colite microscopique (collagénique) en 1986. Durant l'évolution clinique subséquente, des biopsies du côlon ont révélé des caractéristiques pathologiques typiques de colite lymphocytaire et collagénique. La patiente a présenté de la fièvre, des malaises, des céphalées, des bruits vasculaires multiples et un taux de sédimentation élevé. Bien que la vasculite au niveau des gros vaisseaux ait été soupçonnée, la biopsie de l'artère temporale s'est révélée normale. Une aortographie et des cathétérisations artérielles sélectives subséquentes ont révélé des sténoses et des occlusions vasculaires multiples. Malgré le tableau clinique très atypique, une biopsie de l'artère brachiale occluse

Department of Medicine (Gastroenterology), University Hospital and University of British Columbia, Vancouver, British Columbia

Correspondence and reprints: Dr Hugh Freeman, Head, Gastroenterology, ACU F-137

University Hospital (UBC site), 2211 Wesbrook Mall, Vancouver, British Columbia V6T IW5. Telephone (604) 822-7216 or (604) 822-7235

Received for publication January 28, 1993, Accepted May 12, 1993
T WO VASCULITIDES THAT PRIMARILY involve large vessels are Takayasu's arteritis and giant cell arteritis $(1,2)$. The clinical presentations of these two conditions are quite different. Takayasu's arteritis tends to occur in patients less than 40 years old while giant cell vasculitis usually is seen in patients over age 50 years. In these elderly patients, clinical syndromes related to the large vessel vasculitides include polymyalgia rheumatica with musculoskeletal and systemic symptoms (fever, malaise and weight loss) and a syndrome of inadequate circulation, especially involving the cranial vessels, such as the temporal artery, with headache, ocular symptoms, transient ischemic attacks, jaw claudication and facial pain (1). In elderly patients with giant cell arteritis, large vessels other than the temporal artery may also be involved, with impaired circulation to the extremities and resultant upper extremity claudication, rest pains, pulse abnormalities and paresthesias. Although the intestine has not normally been considered a target organ for large vessel vasculitides of either type (1), both ulcerative colitis and Crohn's disease have been associated with either Takayasu's arteritis or giant cell arteritis (3-7). In the case of either form of inflammatory bowel disease, their pathogenetic relationship to these different types of inflammatory arteritides requires elucidation. 
a révélé des caractéristiques de l'artérite à cellules géantes. La corticothérapie a amené une rémission clinique rapide. Le spectre des observations cliniques chez cette patiente confirme la notion selon laquelle la colite collagénique et possiblement d'autres formes de colite microscopique apparentées au plan histologique, comme la colite lymphocytaire, puissent être des marqueurs pathologiques d'une maladie immunologique plus généralisée.

In 1976, collagenous colitis was first described $(8-10)$ as a form of microscopic colitis with a distinctive subepithelial trichrome-positive band of hyaline material in the lamina propria of the mucosal biopsy; using electron microscopy, collagen fibres could be identified (8). Subsequently, an apparently related form of 'microscopic colitis' was reported, called 'lymphocytic colitis' (11). This pathological entity had similar histological features to collagenous colitis but lacked the collagen deposits in the subepithelial region of the mucosa. In some patients, both types of microscopic colitis can be seen (12), and these are invariably associated with watery diarrhea, often recurrent and resistant to common therapies for other forms of inflammatory bowel disease. In addition, the syndrome has been observed almost exclusively in middleaged to elderly females (10). Occasionally, it has also been associated with celiac disease $(11,13,14)$, a condition occasionally complicated by vasculitis (15). Although a number of associated phenomena believed to be 'autoimmune' in type have already been described to date (16-20) in patients with either collagenous or lymphocytic colitis, the full clinical spectrum still requires more detailed definition. This report describes the unusual occurrence of an inflammatory giant cell (brachial) arteritis in an elderly woman with preexistent microscopic (collagenous-lymphocytic) colitis, providing further support to the emerging concept that collagenous colitis may be a manifestation of a more generalized immunological disorder $(19,20)$.

\section{CASE PRESENTATION}

A 55-year-old female was initially seen in March 1986 for evaluation of intermittent watery diarrhea for 20 years. Studies from two other teaching hospitals were reviewed. In 1970, she had fecal cultures, barium radiographs of the upper and lower gastrointestinal tract as well as rigid sigmoidoscopy; all of these were normal. In February 1986, additional fecal cultures, repeat barium radiographs as well as fibroptic endoscopic studies of the upper and lower gastrointestinal tracts were done; these were normal (including small intestinal biopsies). The patient was first seen at University Hospital in April 1986; at that time, painless watery nonbloody diarrhea was present, about three to four times per day, for at least 18 months. Physical examination was normal. Flexible sigmoidoscopy revealed normal-appearing colorectal mucosa with the typical biopsy features of collagenous colitis. Hemogram, multichannel biochemical analysis, serum thyroxin, carotene, iron, folic acid and vitamin $\mathrm{B}_{12}$ were normal. Fecal bacterial cultures for salmonella, shigella, campylobacter, yersinia and aeromonas, examinations for parasites and clostridium toxin assays were negative. Because of a possible drug hypersensitivity to sulpha-containing medications, no pharmacological treatment was prescribed. Symptoms, however, temporarily improved with added dietary fibre. The patient was seen periodically over the next four years, usually because of a recurrence or worsening of watery diarrhea. Repeat fecal bacterial cultures were negative. On separate evaluations, colonoscopic studies were normal. Colorectal mucosal biopsies, however, showed changes of microscopic colitis with the typical features of collagenous colitis present in a patchy or multifocal distribution; as has been reported elsewhere $(11,12)$, in these areas (without typical features of collagenous colitis), only changes of colonic epithelial lymphocytosis were evident.

In August 1990, during a follow-up visit for diarrhea, the patient com- plained of fever, malaise and diminished energy as well as occasional rightsided supra-orbital headaches. Her hemoglobin was $140 \mathrm{~g} / \mathrm{L}$ and white cell count was $10.0 \times 10^{9} / \mathrm{L}$ but her sedimentation rate was $76 \mathrm{~mm} / \mathrm{h}$ (normal 20 $\mathrm{mm} / \mathrm{h}$ ). Other studies (multichannel biochemical analysis, protein electrophoresis and quantitation of immunoglobulins) were normal. Fecal bacterial cultures, parasite studies and toxin assays were negative. A chest $x$-ray and abdominal ultrasound as well as blood and urine cultures were negative. Flexible sigmoidoscopy and biopsy showed features of microscopic colitis. Because of this finding and the reported association of both lymphocytic and collagenous colitis with celiac disease (11. 14), a small bowel barium radiographic study, along with small intestinal biopsies, were done; these were normal. The patient's sedimentation rate increased to $129 \mathrm{~mm} / \mathrm{h}$, and antinuclear antibodies, rheumatoid factor and complement studies were normal. Because of continued intermittent fever, a computed tomography abdominal scan was done in February 1991; this was normal with no abnormality in the spleen, liver, kidneys or retroperitoneal lymph nodes.

In March 1991, the patient was admitted to University Hospital because of persisting symptoms of diarrhea, anemia, an elevated sedimentation rate, and the onset of spontaneous tingling in the right arm and right hand. In hospital, she had four separate episodes of tingling on the right side of her body; each episode lasted minutes and then resolved spontaneously over $1 \mathrm{~h}$. There were no headaches, or visual or neurological sequelae. Examination revealed new large vessel bruits in multiple locations including the right carotid, left subclavian, and both axillary and femoral arteries. The vessels were not palpably tender or thickened. A clinical diagnosis of a large vessel vasculitis, possibly giant cell arteritis or Takayasu arteritis, was considered. Temporal artery biopsy was negative. Arch aortogram and selective catheterization of the right innominate and left subclavian arteries were done. Multiple fusiform areas of narrowing were seen in the vertebral arteries, as well as a 


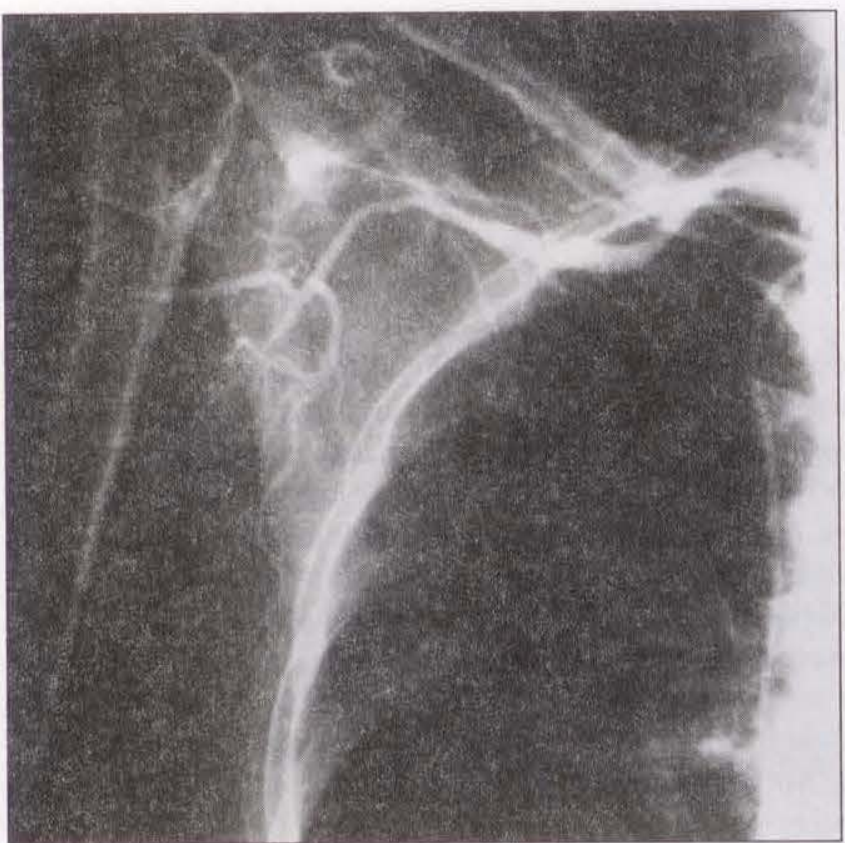

Figure 1) Angiographic studies showing multiple areas of fusiform narrowing of the right subclavian artery extending to the right axillary segment where there is a stenosis of over $90 \%$ through an approximate $6 \mathrm{~cm}$ length of the vessel

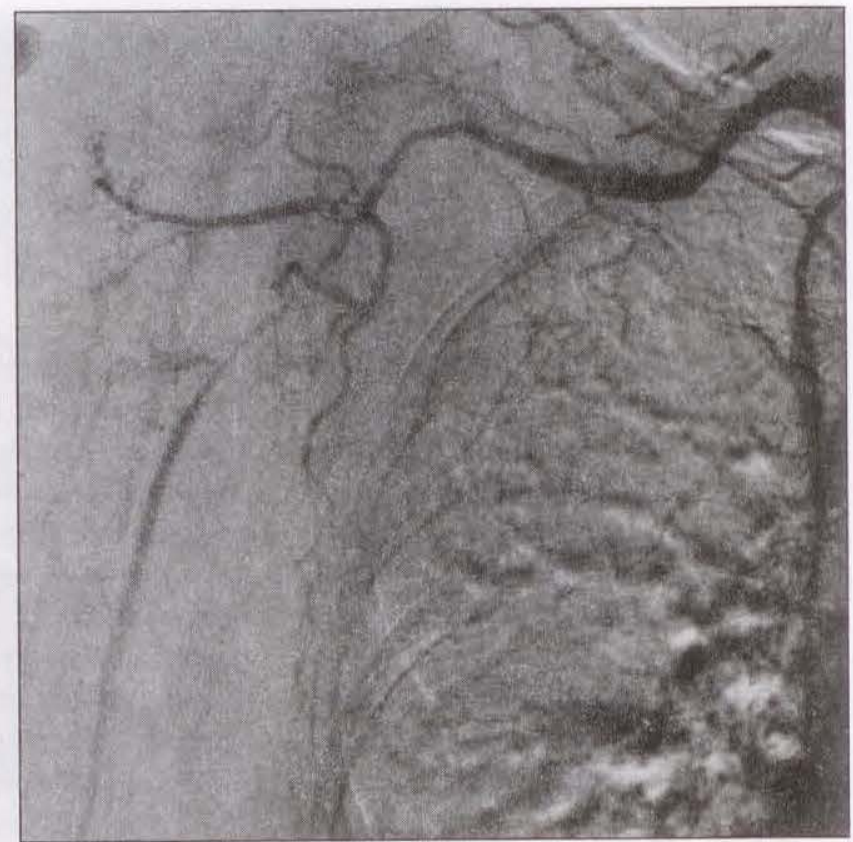

Figure 2) Angiographic studies showing multiple areas of fusiform narrowing of the right subclavian artery extending to the right axillary segment where there is a stenosis of over $90 \%$ through an approximate $6 \mathrm{~cm}$ length of the vessel long smooth stenosis of the right axillary artery over a $6 \mathrm{~cm}$ length and an occlusion in the left axillary artery over a $6 \mathrm{~cm}$ length (Figures 1 to 4 ). A left brachial artery biopsy was done and showed features characteristic of a giant cell arteritis (Figures 5,6). The patient was treated with prednisone 60 $\mathrm{mg}$ daily. Over the next month, her energy improved and anemia resolved (hemoglobin $135 \mathrm{~g} / \mathrm{L}$ ), with a concomitant reduction in the sedimentation rate $(20 \mathrm{~mm} / \mathrm{h})$. Over the next year, steroids were tapered and were discon. tinued in June 1992. Colonoscopy in

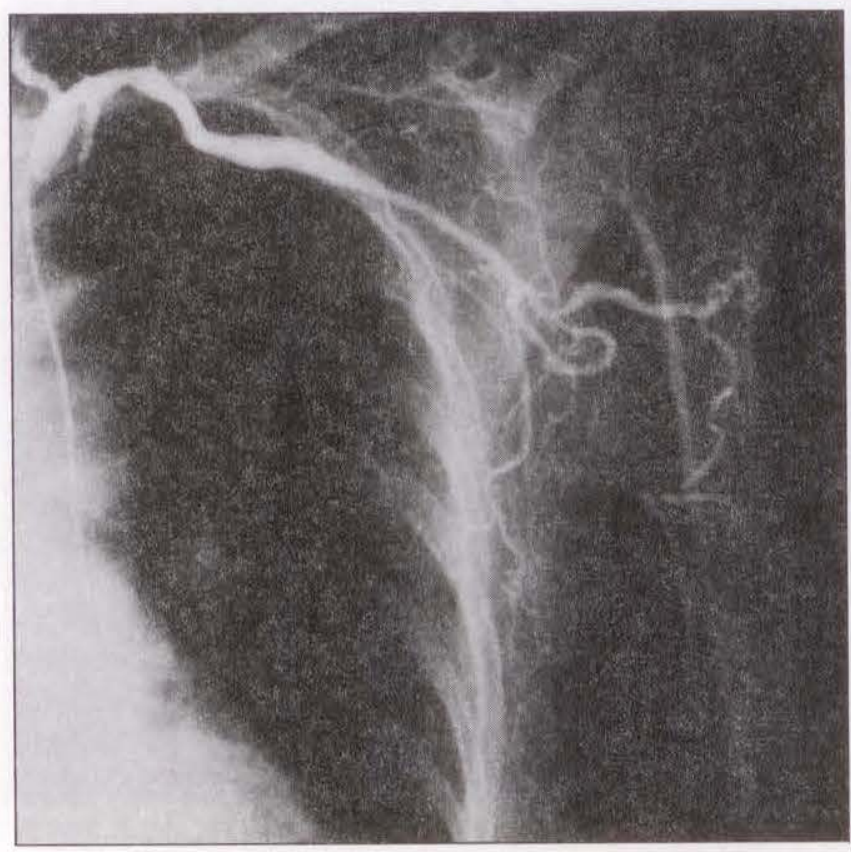

Figure 3) Angiographic studies showing multiple smooth narrowings of the left subclavian artery with complete occlusion of the axillary segment of the artery over a $6 \mathrm{~cm}$ length of the vessel and reconstitution through the circumflex humeral artery. Multiple areas of narrowing are also seen in the left brachial artery

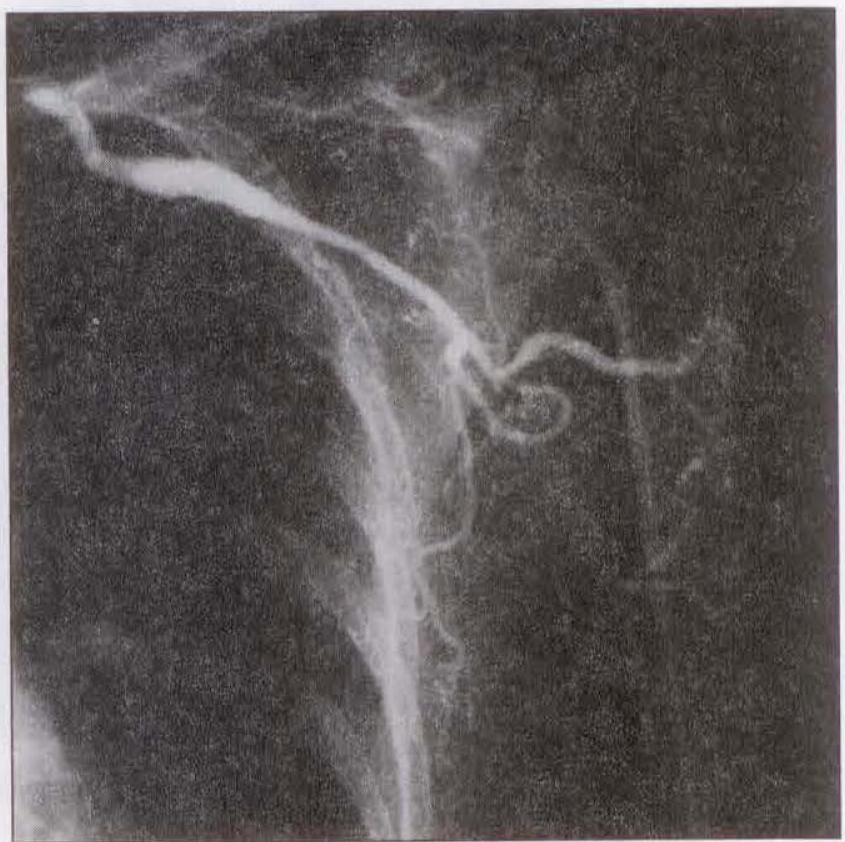

Figure 4) Angiographic studies showing multiple smooth narrowings of the left subclavian artery with complete occlusion of the axillary segment of the artery over $a 6 \mathrm{~cm}$ length of the vessel and reconstitution through the circumflex humeral artery. Multiple areas of narrowing are also seen in the left brachial artery 


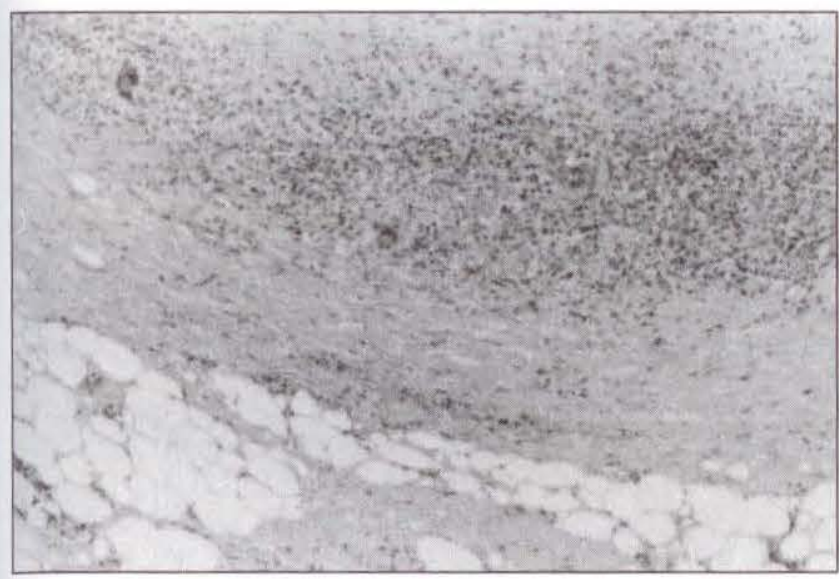

Figure 5) Photomicrograph of a section from the left brachial artery with focal granulomatous inflammatory change and multinucleated giant cells characteristic of giant cell arteritis

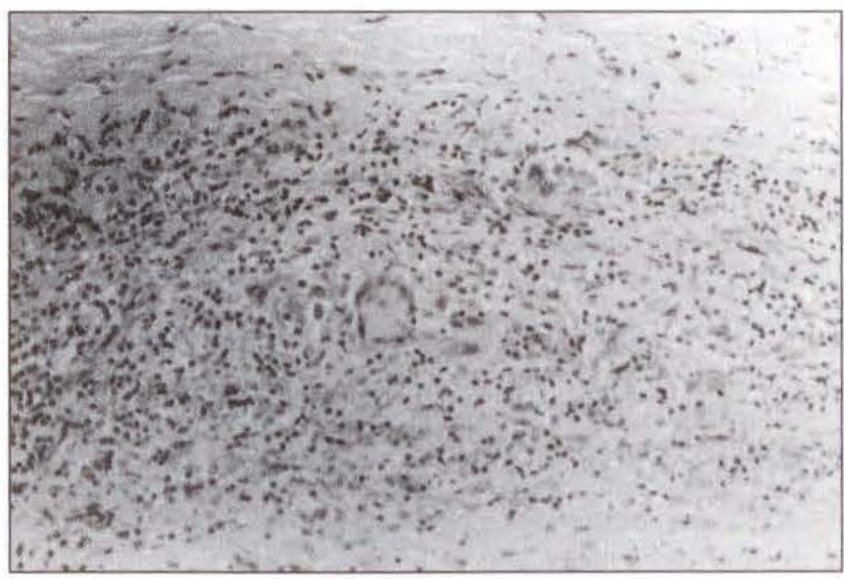

Figure 6) Higher power view, showing focal giant cells, of photomicrograph in Figure 5
October 1992 was nominal although mucosal biopsies from multiple colonic sites showed epithelial lymphocytosis and no evidence of collagenous colitis.

The patient remained completely asymptomatic with a normal sedimentation rate until March 1993 when she had recurrent myalgias in her shoulders and hips, along with arthralgias in her knees and ankles. There were no fever, ocular or neurological symptoms. There was no recurrence of diarrhea but her sedimentation rate increased to 44 $\mathrm{mm} / \mathrm{h}$. Colonoscopic biopsies in April 1993 showed epithelial lymphocytosis but, in the biopsies obtained, no evidence for recurrent collagenous colitis.

\section{DISCUSSION}

This is the first description of giant cell vasculitis associated with microscopic (collagenous-lymphocytic) colitis. Although this observation could simply reflect the presence of two separate and uncommon diseases in the same patient, a more generalized immunological disorder is possible and has been previously hypothesized $(19,20)$. In addition, differing forms of vasculitis have been described in patients with other more commonly recognized types of inflammatory bowel disease, particularly ulcerative colitis or Crohn's disease. These have included two forms of large vessel inflammatory vasculitis: Takayasu's arteritis and, particularly in the elderly patient, giant cell arteritis (most often involving cranial vessels)
(3-7). It is not so surprising, therefore, that giant cell vasculitis can also occur in this form of inflammatory bowel disease. Although selective mesenteric angiograms would have been of interest in the patient described in this report, diagnostic efforts were focused on the most pressing symptoms which led to extensive studies of aortic arch vessels and, eventually, a brachial artery biopsy. These investigations demonstrated that multisite involvement of several vessels was present, associated with the characteristic clinical features of large vessel disease combined with the classical histopathology of giant cell vasculitis.

Vasculitis has been previously recorded in patients with collagenous mucosal inflammatory diseases (9-11) involving other gastrointestinal sites, specifically the small intestine in collagenous sprue (9-11). Vascular histological studies have been very limited in these reports, but in some patients with clinically evident vasculitis, apparent responsiveness to steroid treatment was observed (11). In these patients, the histopathology of large vessels might have been very instructive as some may have represented atypical clinical presentations of giant cell vasculitis, as in the present report with brachial artery and multisite involvement. This could be an important clinical issue since most patients with giant cell vasculitis are over age 50 years, similar to the age of onset gener- ally reported for patients with collagenous colitis as well as for those reported with a collagenous inflammatory mucosal disease process in other gastrointestinal sites, such as the small intestine in collagenous sprue or the stomach in collagenous gastritis (21). Moreover, patients with collagenous disorders of the gastrointestinal tract appear to share many clinical features that might be considered characteristic of a more generalized immunological disorder, including arthropathy or frank arthritis (16-18), thyroid disease (20) and pulmonary fibrosis (19). In large part, these features have been described primarily in patients with longstanding, usually symptomatic, colonic disease rather than in patients with small intestinal involvement with severe panmalabsorption and concomitant nutritional deficits. Possibly, a common immune-mediated pathogenesis is present in both disorders, resulting in altered function of fibroblasts known to be ubiquitous in the wall of large vessels and the mucosal pericryptal sheath (22-24).

\section{REFERENCES}

1. Fan PT, Davis JA, Somer T, Kaplan L, Bluestone R. A clinical approach to systemic vasculitis. Semin Arth Rheum 1980;9:248-304.

2. Churg J, Churg A. Idiopathic and secondary vasculitis: A review. Mod Pathol 1989;2:144-60.

3. Achar KN, Al-Nakib B. Takayasu's arteritis and ulcerative colitis. Am J Gastroenterol 1986;81:1215-7. 
4. Sakhuja V, Gupta KL, Bhasin DK, Malik N, Chugh KS. Takayasu's arteritis associated with idiopathic ulcerative colitis. Gut 1990;31:831-3.

5. Jacob A, Ledingham JG, Kerr AI, Ford MJ. Ulcerative colitis and giant cell arteritis associated with sensorineural deafness. J Laryngol Otol 1990;104:889-90.

6. Lenhoff SJ, Mess AS. Crohn's disease of the colon with Takayasu's arteritis. Postgrad Med J 1982;58:386-9.

7. Beau B, Colasse W, Le Bihan G, Bourreille J. Association of Takayasu's arteritis and inflammatory bowel disease. Semin Hop Paris 1980;56:1841-5.

8. Freeman HJ, Weinstein WM, Shnitka TK, Wensel RH, Sartor VE. Watery diarrhea syndrome associated with a lesion of the colonic basement membrane-lamina propria interface. Ann Royal Coll Phys Surg Can 1976;9:45.

9. Lindstrom CG. Collagenous colitis with watery diarrhea - a new entity? Pathol Eur 1976;11:87-9.

10. Freeman HJ. Collagenous inflammatory mucosal disorders of the gastrointestinal tract. Can J Gastroenterol 1990;4:196-200.

11. Kingham JGC, Levison DA, Ball JA, Dawson AM. Microscopic colitis a cause of chronic watery diarrhea. Br Med J 1982;285:1601-4.
12. Lazenby AJ, Yardley JH, Giardiello FM, Jessurun J, Bayless TM. Lymphocytic ('microscopic') colitis. A comparative histopathologic study with particular reference to collagenous colitis. Hum Pathol 1989;20:18-28.

13. Hamilton I, Sanders S, Hopwood D, Bouchier IA. Collagenous colitis associated with small intestinal villous atrophy. Gut 1986;27:1394-8.

14. Wolber R, Owen D, Freeman HJ. Colonic lymphocytosis in patients with celiac sprue. Hum Pathol 1990;21:1092-6.

15. Doe WF, Evans D, Hobbs JR, Booth CC. Coeliac disease, vasculitis and cryoglobulinemia. Gut 1972;13:112-23.

16. Erlendsson J, Fenger C, Meinicke J. Arthritis and collagenous colitis. Report of a case with concomitant chronic polyarthritis and collagenous colitis. Scand J Rheumatol 1983;12:93-5.

17. Farah DA, Niis PR, Lee FD, McLay A, Russell RI. Collagenous colitis. Possible response to sulfasalazine and local steroid therapy. Gastroenterology 1985;88:792-7.

18. Wengrower D, Pollak A, Olson E, Stalnikowicz R. Collagenous colitis and rheumatoid arthritis with response to sulfasalazine. A case report and review of the literature. J Clin Gastroenterol 1987;9:456-60.

19. Wiener NO. Collagenous colitis and pulmonary fibrosis. Manifestations of single disease? J Clin Gastroenterol 1986;8:677-80.

20. Giardiello FM, Bayless TM, Jessurun J, Hamilton SR, Yardley JH. Collagenous colitis. Physiologic and histopathologic studies in seven patients. Ann Intern Med 1987;106:46-9.

21. Freeman HJ, Piercey JRA, Raine RJ. Collagenous gastritis. Can J Gastroenterol 1989;3:171-4.

22. Pascal RR, Kaye GI, Lane N. Colonic pericryptal fibroblast sheath. Replication, migration, and cytodifferentiation of a mesenchymal cell system in adult tissue. I.

Autoradiographic studies of normal rabbit colon. Gastroenterology 1968;54:835-51.

23. Kaye GI, Lane N, Pascal RR. Colonic pericryptal fibroblast sheath. Replication, migration, and cytodifferentiation of a mesenchymal cell system in adult tissue. III. Fine structural aspects of normal rabbit and human colon. Gastroenterology 1968;54:852-65.

24. Hwang WS, Kelly JSK, Shaffer EA, Hershfield NB. Collagenous colitis. A disease of pericryptal fibroblast sheath? J Pathol 1986;149:33-40. 


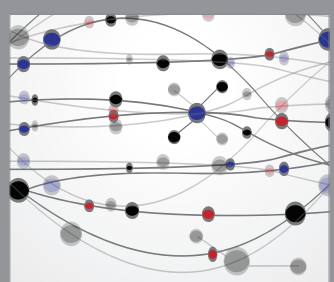

The Scientific World Journal
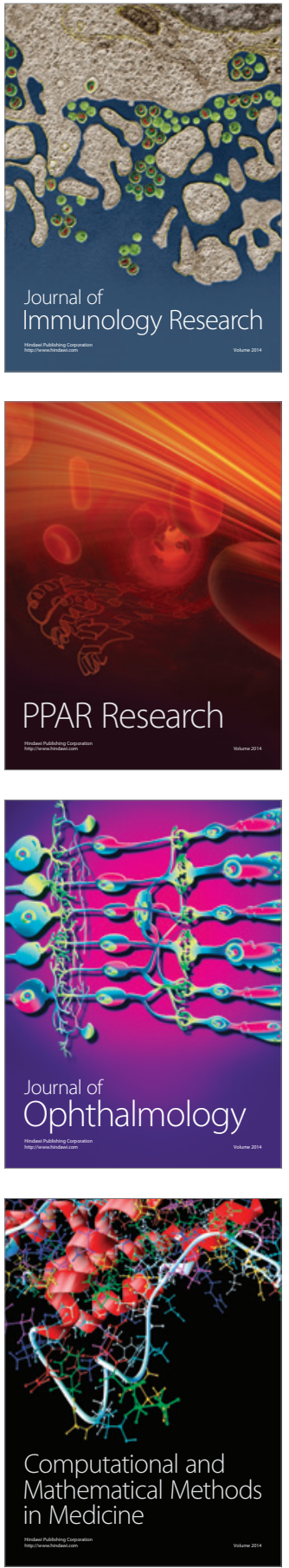

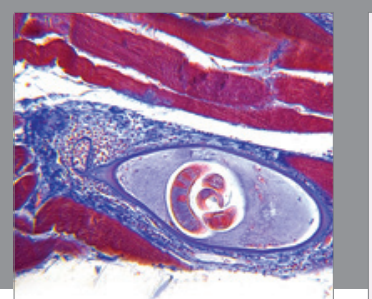

Gastroenterology Research and Practice

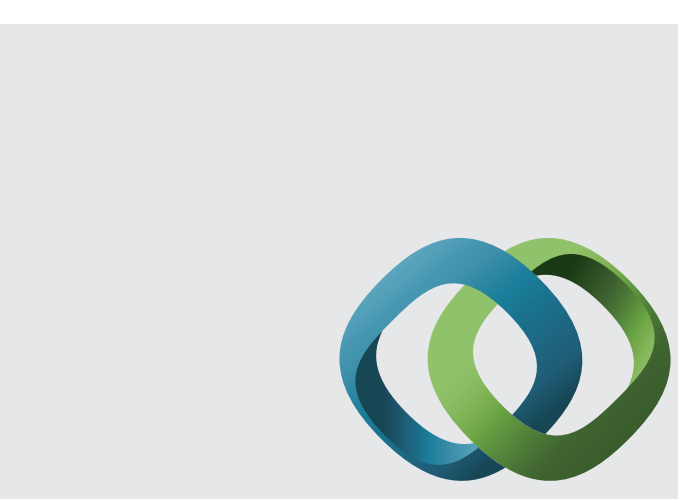

\section{Hindawi}

Submit your manuscripts at

http://www.hindawi.com
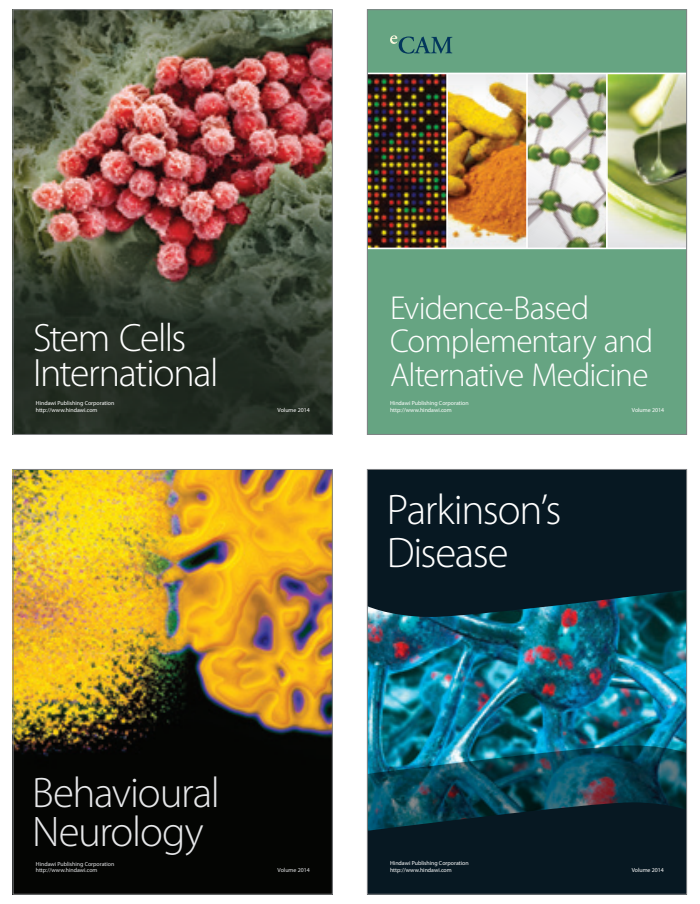
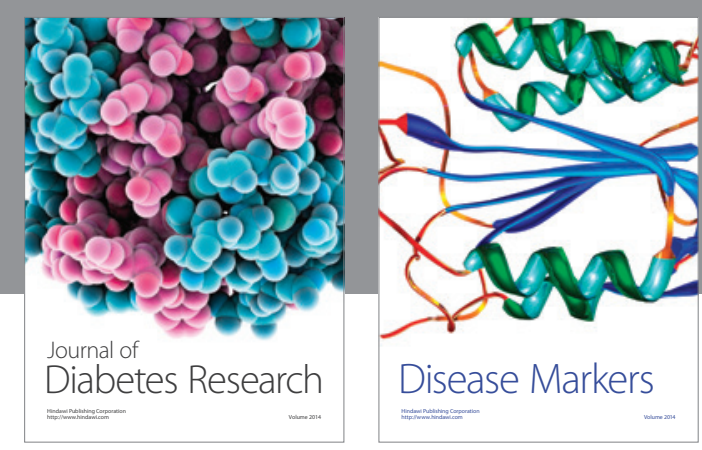

Disease Markers
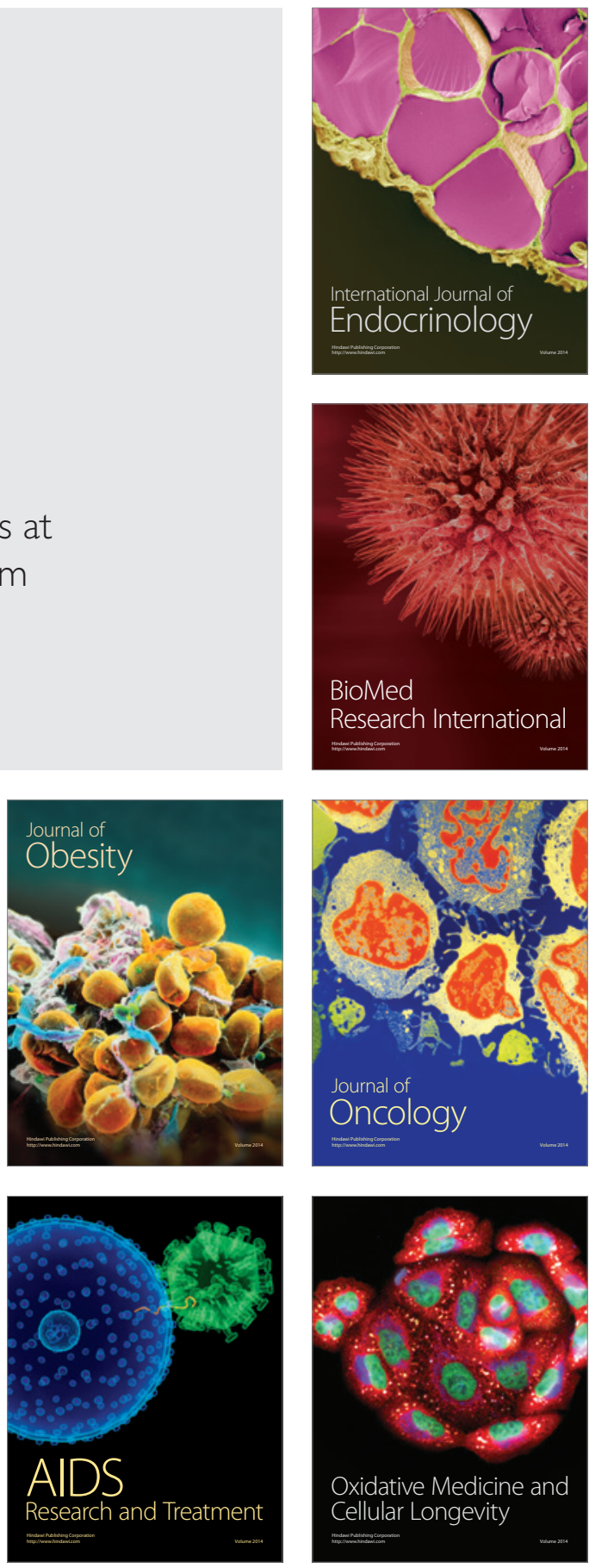